J. Pijar MIPA, Vol. VI No.2, September : 56 - 60

ISSN 1907-1744

\title{
PENGARUH PENERAPAN METODE OBSERVASI YANG DIVARIASIKAN DENGAN LKS WORD SQUARE TERHADAP HASIL BELAJAR BIOLOGI SISWA KELAS VIII SMP NEGERI 8 MATARAM
}

\author{
Eryuni Ramdhayani, Nur Lestari, dan I Wayan Mertha \\ Program Studi Biologi PMIPA FKIP Universitas Mataram \\ Jl.Majapahit No. 62 Mataram 83125
}

\begin{abstract}
Abstak : Penelitian ini bertujuan untuk mengetahui pengaruh penerapan metode observasi yang divariasikan dengan LKS words square terhadap hasil belajar biologi siswa kelas VIII SMP Negeri 8 Mataram Tahun Ajaran 2011/ 2012. Jenis penelitian ini adalah experiment dengan desain penelitian posttest-only control design. Data hasil penelitian berupa hasil belajar (kognitif, afektif dan psikomotor), dan lembar observasi aktivitas guru. Hasil penelitian menunjukkan bahwa nilai rata-rata post-test kelas eksperimen sebesar 77,32 lebih besar dari nilai rata-rata post-test kelas kontrol masing-masing sebesar 70,08. Ketuntasan belajar kelas eksperimen mencapai 92\% dan kelas kontrol mencapai 70\%. Uji hipótesis dengan uji-t polled varian terhadap hasil belajar (Kognitif, afektif, dan psikomotor) antara kelas ekeperimen dan kontrol menunjukkan terdapat perbedaan hasil belajar biologi yang signifikan antara kelas eksperimen dan kontrol. Kesimpulan hasil penelitian ini bahwa penerapanan metode observasi yang divariasikan dengan LKS word square berpengaruh terhadap hasil belajar biologi siswa kelas VIII SMP Negeri 8 Mataram tahun ajaran 2011/2012.
\end{abstract}

Kata kunci : Metode Observasi, LKS Word Square, Hasil belajar

\section{EFFECT OF USING OBSERVATION METHOD VARIED WITH LKS WORD SQUARE FOR THE ACHIVEMENT OF BIOLOGY STUDENTS CLASS VIII IN SMP NEGERI 8}

Abstract : This research is held to know the effect of using the observation method varied with LKS word square to achievement results of student class VIII student of biology SMP Negeri 8 Mataram academic year 2011/ 2012. This kind of research is a experiment with posttest-only control design. The results showed that the average post-test experiment class are 77.32 they are greater than the average post-test control 70.08. Exhaustiveness studied experiment class $92 \%$ and control class $70 \%$. Test the hypothesis with the t-test variant polled on learning outcomes (cognitive, affective, and psychomotor) between classes ekeperimen and control which means that there are biological differences in learning outcomes significantly between experiment and control class. The conclusion of this research is using observation method which varied with the LKS word square is effect for the achievement of biology student class VIII in SMP Negeri 8 Mataram academic year 2011/2012.

Keywords : observation method, LKS Word Square, achievement

\section{PENDAhuluan}

Pendidikan Biologi merupakan bagian dari sains yang menekankan pada pemberian pengalaman secara langsung. Karena itu siswa perlu dibantu untuk mengembangkan sejumlah keterampilan supaya mereka mampu menjelajahi alam sekitar serta dirinya sendiri. Kenyataan yang banyak dijumpai di lapangan adalah pembelajaran IPA yang berpusat pada guru sebagai pemberi pengetahuan bagi siswa, penyampaian materi pelajarannya cenderung masih didominasi dengan metode ceramah. Siswa kurang berperan aktif dalam proses pembelajaran untuk membangun dan menemukan sendiri melalui interaksi dengan lingkungannya, sehingga siswa hanya manghafalkan fakta-fakta dari buku dan bukan dari hasil menemukan serta membangun sendiri pengetahuannya. Berdasarkan hasil studi intensif mengenai pola pembelajaran dan pemahaman siswa menyimpulkan bahwa proses pembelajaran cenderung berorientasi pada buku pelajaran saja dan tidak terkait dengan kehidupan sehari-hari [1].

Salah satu masalah yang dialami siswa yaitu sulitnya siswa untuk memahami konsep akademik seperti yang diajarkan selama ini, hal ini disebabkan beberapa guru hanya menyampaikan materi menggunakan sesuatu yang abstrak dengan menerapkan metode ceramah. Pembelajaran yang berorientasi pada target penguasaan materi terbukti hanya mampu mengantarkan siswa mengingat - ingat materi pelajaran dalam waktu yang relatif pendek, tetapi seringkali anak tidak memahami dan mengetahui secara mendalam, pengetahuan yang didapat hanya bersifat hafalan yang menyebabkan anak akan mudah lupa, sehingga gagal dalam membekali anak untuk memecahkan masalah dalam waktu yang lama [2].

Berdasarkan hasil observasi di SMP Negeri 8 Mataram di kelas VIII yang terdiri dari tujuh kelas yaitu kelas VIIIA, VIIIB, VIIIC, VIIID, VIIIE, VIIIF, VIIIG kebanyakan suasana pembelajaran masih monoton, aktivitas siswa kurang dan berdasarkan dari hasil wawancara dengan beberapa siswa mengakui proses pembelajaran cendrung membuat mereka bosan melakukan proses belajar. Hal ini berdampak pada hasil belajar siswa yang dilihat dari daftar nilai ulangan semester genap kenaikan kelas siswa tahun ajaran 2010/2011, dimana dari ketujuh kelas tersebut masih terdapat beberapa kelas yang nilai rata-rata siswa terbilang rendah dari KKM yang sudah ditentukan oleh sekolah pada pelajaran biologi yaitu kurang dari 70 . 
Pengaruh Penerapan Metode Observasi .....

Tabel 1. Rata-rata nilai ulangan Biologi kelas VII Semester Genap di SMP Negeri 8 Mataram Tahun Ajaran 2010/2011.

\begin{tabular}{|l|l|l|l|l|l|l|}
\hline \multicolumn{7}{|c|}{ Nilai Rata-Rata Kelas } \\
\hline VII A & VII B & VII C & VII D & VII E & VII F & VII G \\
\hline 72,5 & 71,27 & 61,97 & 61,24 & 59,76 & 59,05 & 67 \\
\hline
\end{tabular}

Kegiatan belajar mengajar sebaiknya guru tidak hanya menyampaikan konsep dan teori saja tetapi juga menekankan pada bagaimana caranya agar siswa dapat benar-benar memahami konsep dan teori tersebut. Agar dapat memahami konsep dan teori maka siswa perlu mengkomunikasikan. Guru harus dapat menggunakan pendekatan dan metode maupun model pembelajaran yang tepat. Guru sering menggunakan metode yang kadangkadang tidak disesuaikan dengan kondisi siswa sebagai peserta didik, sifat materi bahan ajar, fasilitas-media yang tersedia dan kondisi guru itu sendiri. Oleh karena itu, guru sebagai salah satu faktor penentu keberhasilan belajar siswa, diharapkan mampu menciptakan inovasi-inovasi baru dalam pembelajaran, dan dapat membawa perubahan belajar bagi siswa. Dalam pembelajaran, guru harus pandai-pandai memilih pendekatan maupun strategi pembelajaran yang sesuai dengan kemampuan siswa sebagai peserta didik, sehingga mampu membawa perubahan belajar siswa dan meningkatnya hasil belajar dari siswa tersebut, salah satunya adalah pendekatan kontekstual.

Dengan melihat permasalahan di atas, salah satu upaya untuk meningkatkan hasil belajar adalah dengan menerapkan metode observasi yang divariasikan dengan LKS word square. Metode observasi merupakan salah satu strategi pembelajaran yang menggunakan pendekatan kontekstual dan media asli dalam rangka membelajarkan siswa yang mengutamakan kebermaknaan proses belajar [3]. LKS word square merupakan salah satu media pembelajaran yang di dalamnya terdapat unsur permainan, sehingga anak tidak merasa bosan dan dapat menarik minat dan menambah motivasi belajar siswa. Kelebihan LKS word square cenderung menggali pengetahuan siswa dan menarik minat siswa dalam mengunakan buku sumber pelajaran biologi.

Berdasarkan uraian di atas akan dilakukan penelitian untuk mengetahui "Pengaruh Penerapan Metode Observasi Yang Divariasikan Dengan LKS Word Square Terhadap Hasil Belajar Biologi Siswa Kelas VIII SMP Negeri 8 Mataram Tahun Ajaran 2011/2012".

\section{METODE PENELITIAN}

Jenis penelitian ini adalah penelitian eksperimen, dimana peneliti sengaja membangkitkan timbulnya suatu kejadian atau keadaan, kemudian diteliti bagaimana akibatnya. Populasi dalam penelitian ini adalah seluruh siswa kelas VIII SMP Negeri 8 Mataram yang berjumlah 7 kelas dengan jumlah siswa secara keseluruhan 272 siswa. Eksperimen selalu dilakukan dengan maksud untuk melihat akibat suatu perlakuan [4]. Desain penelitian yang digunakan adalah Posttest - only control design, dalam
(Eryuni Ramdhayani, Nur Lestari, Ddan I Wayan Mertha) design ini terdapat dua kelompok yang masing-masing dipilih secara random. Kelompok pertama diberi perlakuan dan kelompok yang lain tidak. Kelompok yang diberi perlakuan disebut kelompok eksperimen dan kelompok yang tidak diberi perlakuan disebut kelompok kontrol. Pengaruh adanya perlakuan (treatment) adalah (Q1:Q2) [5]. Instrumen dalam penelitian ini yang digunakan untuk memperoleh data, yaitu tes hasil belajar siswa (post-test), lembar observasi aktivitas mengajar guru, lembar penilaian psikomotor dan afektif.

Penelitian ini dilaksanakan dalam tiga tahapan yang terdiri dari tahap perencanaan, pelaksanaan tindakan dan evaluasi. Adapun kegiatan yang dilakukan pada tahap perencanaan untuk menerapkan metode observasi yang divariasikan dengan LKS word square, maka peneliti mempersiapkan RPP, rubrik penilaian afektif dan psikomotor siswa, uji instrument dan lembar aktivitas guru. pada tahap pelaksanaan tindakan langkah-langkah yang dilaksanakan adalah memberikan pre-test pada masingmasing kelas yaitu kelas kontrol dan kelas eksperimen untuk mengetahui kemampuan awal siswa sebelum diberikan perlakuan berupa metode observasi yang divariasikan dengan LKS word square. Memberikan perlakuan pada kelas eksperimen berupa metode observasi yang divariasikan dengan LKS word square dan kelas kontrol diterapkan metode ceramah.

Pada akhir tindakan dilakukan evaluasi hasil belajar (post-test) untuk mengetahui hasil belajar atau penguasaan siswa terhadap materi yang dipelajari secara individu.

Selama pembelajaran berlangsung dilakukan pengamatan terhadap afektif siswa dan psikomotor siswa. Untuk mengetahui ketercapaian indikator dilakukan uji akhir (post-test), hasil penilaian afektif dan psikomotor siswa yang teknik analisis datanya menggunakan analisis statistik inferensial yaitu di uji-t polled varian setelah diketahui data normal dan homogen, Uji statistik ini untuk mengetahui perbedaan hasil belajar antara kelas eksperimen dan kontrol sehingga dapat diketahui pengaruh antara kelas yang diberi perlakuan berupa metode observasi yang divariasikan dengan LKS word square dengan kelas yang diajarkan dengan metode ceramah.

\section{HASIL PENELITIAN \\ 1. Hasil Observasi Aktivitas Guru}

Observasi pembelajaran yang dilakukan dengan menggunakan metode observasi yang divariasikan dengan LKS word square difokuskan pada aktivitas guru ketika kegiatan belajar mengajar (KBM) berlangsung. Observasi ini dilakukan sebanyak 3 kali pertemuan dengan alokasi waktu masing-masing pertemuan yaitu 2 jam pelajaran ( 2 x 30 menit). Pada setiap pertemuan diamati langkahlangkah dalam pembelajaran metode observasi yang divariasikan dengn LKS word square mulai dari tahap pemberian motivasi, apersepsi, penjelasan metode, memfasilitasi diskusi, melakukan permainan LKS word square, pengaturan waktu, pendampingan dalam KBM, Pendampingan dalam kegiatan kelompok, Presentasi hasil karya, menciptakan suasana yang kondusif dan menutup kegiatan pembelajaran. menunjukkan bahwa hasil observasi aktivitas mengajar guru berdasarkan Lembar 
J. Pijar MIPA, Vol. VI No.2, September : 56 - 60

Observasi Guru menunjukkan, bahwa pada pertemuan I guru melaksanakan aspek kegiatan pembelajaran secara keseluruhan dengan baik. Pertemuan I pengaturan waktu dalam kegiatan pembelajaran masih kurang efektif, penanganan pada masing-masing kelompok masih belum menyeluruh, serta pemberian kesempatan pada siswa untuk mengemukakan hasil diskusi masih kurang. Pertemuan II guru melaksanakan aspek kegiatan pembelajaran secara keseluruhan secara baik hingga baik sekali. Sementara pada pertemuan III dapat dikatakan sempurna karena pengelolaan kelompok untuk melakukan kegiatan observasi baik sekali. Begitupula hasil observasi aktivitas guru kelas kontrol.

\section{Ketuntasan Belajar}

Data hasil belajar siswa kelas kontrol maupun ekpserimen juga dianalisis untuk mengetahui ketuntasan belajar perorangan dan ketuntasan belajar kelompok untuk nilai akhir siswa (kongnitif, psikomotor, afektif).

\subsection{Ketuntasan Belajar Perorangan}

Ketuntasan belajar perorangan tercapai apabila daya serap siswa e" 70 (KKM) yang telah ditetapkan oleh sekolah. Dari hasil analisis ketuntasan belajar pada kelas eksperimen diperoleh bahwa dari 38 orang sebanyak 35 orang memperoleh nilai e" 70 dan 3 orang yang memperoleh nilai $<70$, sedangkan hasil analisis ketuntasan belajar pada kelas kontrol yang terdiri dari 37 orang sebanyak 26 orang yang memperoleh nilai e" 70 dan 11 orang yang memperoleh nilai $<70$

\subsection{Ketuntasan Belajar kelompok}

Ketuntasan belajar kelompok dikatakan tercapai apabila $85 \%$ siswa mencapai daya serap e" 70 yang ditetapkan oleh sekolah. Hasil analisis data diperoleh bahwa pada kelas eksperimen persentase siswa yang berhasil mencapai daya serap e" 70 sebesar $92 \%$ dan persentase siswa yang gagal mencapai daya serap e" 70 sebesar $8 \%$. Hal ini menunjukkan kelas eksperimen telah mencapai ketuntasan belajar kelompok. Sedangkan Pada kelas kontrol persentase siswa yang berhasil mencapai daya serap e" 70 sebesar $70 \%$, sedangkan persentase siswa yang gagal mencapai daya serap e" 70 sebesar $30 \%$. Dengan demikian dapat dikatakan bahwa kelas kontrol belum mencapai ketuntasan belajar kelompok. Hasil ketuntasan belajar pada kelas eksperimen dan kelas kontrol tersebut terangkum pada Tabel 2 dibawah ini:

Tabel 2. Hasil Analisis Ketuntasan Belajar Kelas Eksperimen dan Kelas Kontrol

\begin{tabular}{|l|l|l|l|}
\hline \multirow{3}{*}{ Kelas } & \multicolumn{1}{|c|}{ Hasil } & \multicolumn{2}{|c|}{ Indikator } \\
\cline { 3 - 4 } & & Berhasil & Gagal \\
\hline Eksperimen & Jumlah siswa (orang) & 35 & 3 \\
\cline { 2 - 4 } & Persentase (\%) & $92 \%$ & $8 \%$ \\
\cline { 2 - 4 } & Ketuntasan & $=70$ & $<70$ \\
\hline \multirow{3}{*}{ Kontrol } & Jumlah siswa (orang) & 26 & 11 \\
\cline { 2 - 4 } & Persentase (\%) & $70 \%$ & $30 \%$ \\
\cline { 2 - 4 } & Ketuntasan & $=70$ & $<70$ \\
\hline
\end{tabular}

\section{Analisis Hasil Belajar Siswa 3.1 Penilaian Kognitif}

Selama proses pembelajaran ( $3 \mathrm{x}$ pertemuan) tidak semua siswa mengikuti proses belajar mengajar atau ada di antara mereka yang absen. Lalu nilai siswa yang tidak mengikuti pre-test ataupun tidak mengikuti post test tidak diikutkan dalam analisis data, sehingga data jumlah siswa pada kelas VIIIb adalah 38 siswa dan jumlah siswa pada kelas VIIIc adalah 37.

\subsubsection{Hasil Pretes}

Kemampuan awal siswa kelas eksperimen dan kelas kontrol SMPN 8 Mataram dalam memahami materi gerak pada manusia dapat diketahui dari pemberian pretes. Pengambilan data untuk nilai pretes menggunakan instrumen pengumpulan data yang sudah divalidasi sebanyak 30 soal. Hasil pretes siswa pada kelas kontrol diperoleh nilai terendah 37 dan nilai tertinggi 67 dengan nilai rata-rata 46,64 , sedangkan hasil pre test siswa pada kelas eksperimen diperoleh nilai terendah 40 dan nilai tertinggi 70 dengan nilai rata-rata 50,24. Berdasarkan data diatas dan uji beda dapat dikatakan kemampuan awal dari siswa pada kelas ekpserimen dan kelas kontrol sama karena tidak adanya perbedaan nilai yang signifikan. Perbandingan nilai pre-test terendah dan pre-test tertinggi dari kedua kelompok dapat dilihat pada Gambar 1 di bawah ini :

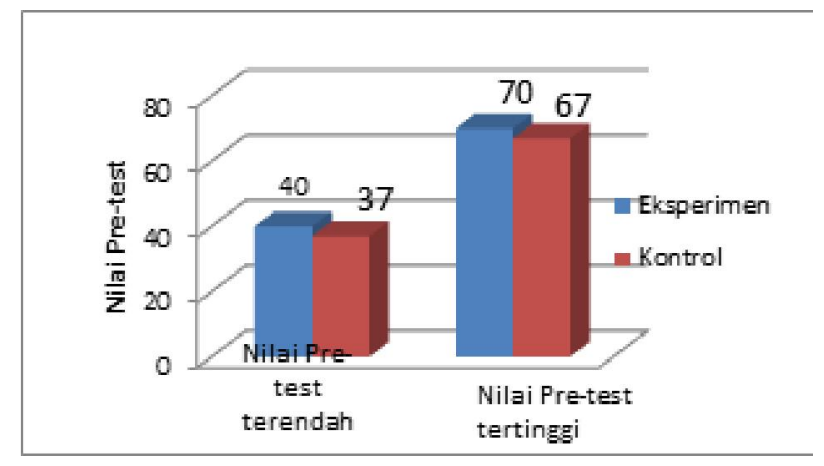

Berdasarkan Gambar 1 menunjukkan bahwa nilai pre-test kelompok kontrol maupun kelompok eksperimen bervariasi namun tidak ada perbedaan yang signifikan. Hal ini dapat dikatakan bahwa kemampuan awal siswa sama.

\subsubsection{Hasil Post tes}

Hasil post tes pada kelas kontrol diperoleh nilai terendah 40 dan nilai tertinggi 90 dengan nilai ratarata 70,08, sedangkan hasil post test pada kelas ekserimen diperoleh nilai terendah 53 dan nilai tertinggi 93 dengan nilai rata-rata 77,32 . Hal ini menunjukkan bahwa pembelajaran dengan metode observasi yang divariasikan dengan LKS word square dapat meningkatkan hasil belajar. Perbandingan nilai Post-test terendah dan posttes tertinggi dari kedua kelompok dapat dilihat pada Gambar 2 di bawah ini : 
Pengaruh Penerapan Metode Observasi ..... (Eryuni Ramdhayani, Nur Lestari, Ddan I Wayan Mertha)

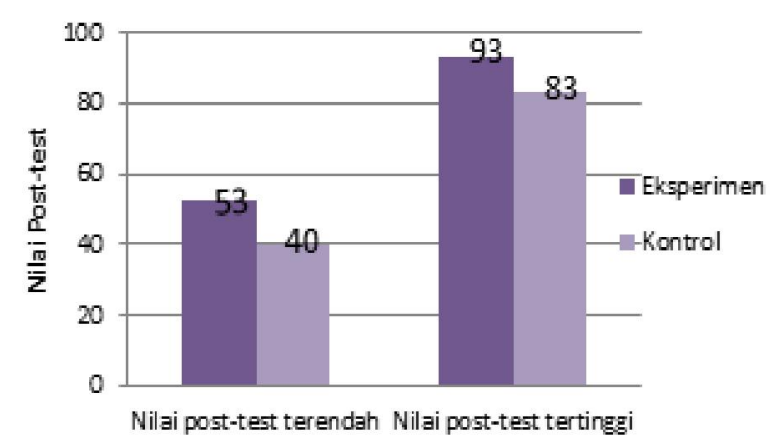

Gambar 2. Grafik Perbandingan Nilai Post- test pada Kelompok Kontrol dan Eksperimen

Berdasarkan grafik 2 perbandingan nilai Post-test pada kelompok Kontrol dan Eksperimen memiliki kemampuan siswa yang bervariasi mulai dari nilai terendah sampai ke nilai tertinggi dimana pada nilai post test terendah lebih tinggi kelas eksperimen dari pada kelas kontrol $(53>40)$, demikian juga terhadap nilai post-test tertinggi di peroleh pada kelas eksperimen (93>83).

Perbandingan nilai rata-rata pre-test dan post-test untuk kedua kelompok dapat dilihat lebih rinci pada Gambar 3 di bawah ini :

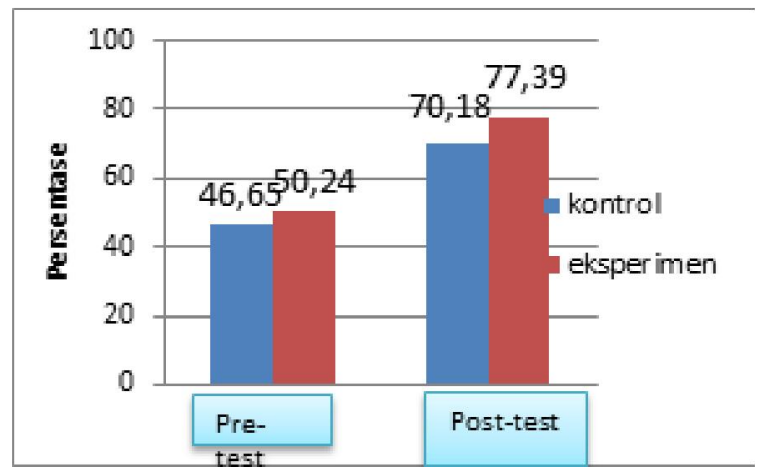

Gambar 3. Perbandingan Nilai rata-rata Pre-test dan Post-test pada Kelompok Kontrol dan Eksperimen.

Tabel 3. Rata-rata penilaian kognitif, psikomotor dan afektif siswa

\begin{tabular}{|c|l|l|l|l|l|}
\hline Kelas & $\begin{array}{c}\text { Jumlah } \\
\text { Siswa }\end{array}$ & $\begin{array}{l}\text { Rerata } \\
\text { kognitif }\end{array}$ & $\begin{array}{l}\text { Rerata } \\
\text { Afektif }\end{array}$ & $\begin{array}{c}\text { Rerata } \\
\text { Psikomotor }\end{array}$ & $\begin{array}{l}\text { Rata- } \\
\text { rata }\end{array}$ \\
\hline $\begin{array}{c}\text { Eksperimen } \\
\text { (VIIIb) }\end{array}$ & 38 & 77,32 & 75,47 & 75,21 & 76 \\
\hline $\begin{array}{c}\text { Kontrol } \\
\text { (VIIIc) }\end{array}$ & 37 & 70,08 & 70,49 & 69,89 & 70 \\
\hline
\end{tabular}

Berdasarkan Tabel 4.5 dapat dilihat hasil akhir siswa dari nilai rata-rata kognitif (post-test), psikomotor dan afektif siswa, dimana hasil rata-rata siswa dari ketiga nilai tersebut untuk kelas kontrol yaitu 70,00 dan kelas eksperimen 76,00. Hal ini menunjukkan bahwa hasil belajar siswa dengan menerapkan pembelajaran dengan metode observasi yang divariasikan dengan LKS word square lebih tinggi dibandingkan kelas kontrol.

\section{Hasil Uji Hipotesis}

Setelah melakukan uji normalitas dan homogenitas selanjutnya dilakukan uji hipotesis untuk mengetahui tingkat kemampuan siswa. Uji hipotesis dilakukan terhadap hasil belajar kongnitif, psikomotor dan afektif siswa yang telah dirata-ratakan. Dari data tes hasil belajar ketiga ranah tersebut setelah dirata-ratakan diperoleh, nilai rata-rata pada kelas kontrol lebih rendah dibandingkan dengan kelas eksperimen (lampiran 10) yang diajarkan dengan menggunakan metode observasi yang divariasikan dengan LKS word square. Berdasarkan analisis uji-t (lampiran 12) diperoleh $t_{\text {hitung }}$ lebih besar dari $t_{\text {tabel }}(4,2>$ 3,84), maka Ho ditolak dan Ha diterima. Sehingga dapat disimpulkan ada pengaruh penggunaan metode observasi yang divariasikan dengan LKS word square terhadap hasil belajar biologi siswa kelas VIII SMP Negeri 8 Mataram Tahun Ajaran 2011/2012. Adapun hasil uji hipotesis (pihak kanan) pada taraf kesalahan 5\% dan db 73 dapat dilihat pada Tabel 4.9 di bawah ini.

Tabel 4. Hasil Uji-t Nilai Kognitif, Afektif, dan Psikomotor

\begin{tabular}{|c|c|c|}
\hline$t_{\text {hitung }}$ & $t_{\text {tabel }}$ & Keterangan \\
\hline 4,2 & 3,84 & $t_{\text {hitung }}>t_{\text {tabel }}$ \\
\hline & & \\
\hline
\end{tabular}

Dari hasil analisis terlihat bahwa $\mathrm{t}_{\text {hitung }}>\mathrm{t}_{\text {tabel }}$, sehingga Ho ditolak dan Ha diterima. Dengan demikian, dapat disimpulkan bahwa pembelajaran dengan menggunakan metode Observasi yang divariasikan dengan LKS word square berpengaruh terhadap hasil belajar biologi siswa kelas VIII SMP Negeri 8 Mataram tahun ajaran 2011/2012.

\section{PEMBAHASAN}

Berdasarkan hasil penelitian dan analisa data yang dilakukan, maka dapat dijelaskan bahwa penggunaan metode observasi yang divariasikan dengan LKS word square dapat meningkatkan hasil belajar biologi siswa kelas VIII SMPN 8 Mataram tahun pelajaran 20011/2012. Adanya peningkatan hasil belajar biologi siswa dengan menggunakan metode observasi divariasikan dengan LKS word square dapat dilihat dari hasil penilaian kognitif siswa yaitu nilai post-test siswa. Skor rata-rata pos-test kelas eksperimen meningkat menjadi 77,32 dari hasil pre-test siswa yaitu 50,23 lebih tinggi dibandingkan nilai rata-rata pos-test kelas kontrol yaitu 70,08 yang meningkat dari hasil pre-test yaitu 46,64. Dari hasil penilaian kognitif yaitu nilai post-test siswa pada kedua kelas menunjukkan adanya perbedaan nilai rata-rata yang cukup signifikan antara kelas eksperimen dan kelas kontrol.

Peningkatan hasil belajar dengan penerapan metode observasi yang divariasikan dengan LKS word square di materi sistem gerak pada manusia disebabkan karena metode ini memanfaatkan media asli maupun tiruan dan gambar sebagai media pembelajaran sehingga siswa 